have been buried purposely, has been found in a brick enclosure to the east of the Math. Among this pottery one type has a series of spouts, in number from four to thirty-four and of various designs. Most of the vessels bear representations of snakehoods. This fact is taken as a confirmation of the theory that the site was sacred to the worship of the Nagas or snake-goddesses. Pottery with multiple spouts is not known from other sites in India. The popular name of Maniyar Math, it is thought, may preserve a tradition of Mant Naga, the preserver and rain-giver of Rajagriha. If this indeed be so, it is suggested that these vessels with their multiple channels were the votive offerings of suppliants for rain, which were deposited in the compound of the shrine. Serpent worship at Raigir can be traced back to the third century B.c. and still persists as a popular cult. In the course of excavations carried out on behalf of the Raffles Museum, Singapore, on the Phinsoon Estate at Sungei Siput, Malacca, Prof. Van Stein Callenfels, the distinguished authority on the archæology of the Malayan archipelago, it is reported by Reuter, has discovered a number of human skeletons believed to date from about 2,500 B.c.

\section{The Approach to the Absolute Zero}

ThE Science Museum, South Kensington, has recently performed a most useful public service in arranging, in connexion with the Very Low Tem. peratures Exhibition, for a series of demonstrations and lectures by eminent authorities on recent scientific and technical developments. The series was concluded on Wednesday, May 27, by Prof. F. Simon, late of Berlin and Breslau and now of the Clarendon Laboratory, Oxford. Of the problems which can be investigated by experiment in the new temperature region below $1^{\circ}$ Absolute, one of the most interesting is the specific heat of paramagnetic salts. In experiments carried out in conjunction with Kürti, Rollin and Lainé with the huge electromagnet of the Paris Academy of Sciences, it has been proved that the paramagnetic salts used become ferromagnetic at very low temperatures, showing Curie points of about $0 \cdot 01^{\circ}$ Absolute (see p. 961). The small helium liquefier used in the experiments was transported from Oxford. At the Science Museum, Prof. Simon succeeded in demonstrating a temperature of $0.12^{\circ}$ Absolute, a noteworthy achievement, of which Prof. Simon and his co-workers, Mr. G. L. Pickard and Mr. A. H. Cooke, who were responsible for erecting the apparatus in the Science Museum and for the fact that the demonstration went off without a hitch, may well be proud. The magnet used in the experiment was lent by the Imperial College of Science and Technology; the hydrogen and helium pumps by Messrs. W. Edwards and Co.; the Cambridge Instrument Co., Ltd., provided a galvanometer. The limiting temperature region for this method lies between $0.01^{\circ}$ and $0.001^{\circ}$ Absolute. Further reduction of temperature will depend on the use of nuclear paramagnetism, starting at about $0.01^{\circ}$ Absolute. Even to this method there will be a temperature limit, and the distance from the absolute zero, although very small when measured in degrees, is in reality an infinity. Although this unique series of lectures has now come to an end, the Exhibition of Very Low Temperatures will continue until the end of June. The Exhibition has so far attracted more than 140,000 visitors, and interest in it has not in any way diminished during the three months in which it has been on view.

\section{Maiden Voyage of the Queen Mary}

Britain's newest and finest liner, the Queen Mary, left Southampton Docks on Wednesday, May 27, and entered New York Harbour about four and a half days later after successfully completing her maiden trans-Atlantic trip. Whatever may have been the results of this crossing from the point of view of marine navigation, a new standard was set up in radio communication by the most successful completion of a series of daily broadcasting programmes throughout the voyage. Never before has the whole world been able to follow so closely the daily happenings on board an ocean liner. The progress made in this application of the art of radio communication is illustrated by a note from a special correspondent of The Times, who recalled that he was one of the only two journalists on board the Mauretania on her maiden voyage to New York nearly thirty years ago: his instructions were to send not more than twelve words a day by wireless, and to post an article from New York. In contrast with this, the Queen Mary carried about 150 journalists, and some twenty broadcast commentators of various nationalities. During the voyage, more than sixteen hours actual broadcasting took place from the ship, while many hundreds of wireless messages of all kinds were sent to all parts of the world. To enable this work to be carried out, the normal wireless installation in the Queen Mary (which was referred to in NATURE of January 18 last) was supplemented by special equipment fitted by the British Broadcasting Corporation. More than twenty microphones were fitted in various parts of the ship so that the general life on board could be described direct from the scene of activity in the course of the daily broadcasting programme. Each evening, listeners to British stations were provided with an interesting commentary direct from the Queen Mary, while on one afternoon a special programme was arranged for schoolchildren.

These broadcasts were received in Great Britain via the ship-to-shore radio-telephone service of the Post Office; they were naturally relayed through the Empire system, and the high standard of performance attained is greatly to the credit of all those concerned with the arrangements. Similar programmes were arranged by the appropriate authorities for listeners in America, Denmark, France and Holland. The climax of this radio sound-picture was provided by the joint programme arranged by the B.B.C. and the National Broadcasting Company of America, as the Queen Mary proceeded up the 
Hudson River to her pier in New York Harbour on the completion of her voyage on Monday, June 1. The thrilling scenes which accompanied the superb reception given by the hundreds of thousands of spectators were described by commentators at various vantage points, such as the quay front, a tug accompanying the giant liner, an aeroplane flying overhead and a special announcer located seventy stories up on the Radio City building. Since much of this programme had to be relayed over two or more radio links with the intermediate land-line connexions, the high average standard of the broadcasts illustrates the tremendous possibilities which result from the modern technique and organisation of this branch of communications engineering.

\section{Anniversary of Marconi's First Patent}

Forty years ago on June 2, Marconi filed the application for his first patent for a wireless invention. That patent-No. 12039 of 1896 -described the use of Marconi's sensitive tube receiver, or coherer, connected to an earth and elevated aerial and the tuning of the transmitting and receiving circuits with each other. Since that time nearly 800 patents have either been granted to Marconi and the Marconi companies, or are pending, for the inventions and developments in wireless telegraphy and telephony and broadcasting. The first British ship was equipped with Marconi apparatus in 1901. To-day, more than 3,000 British ships carry Marconi wireless installations, and thousands of people owe their lives to its use. Wireless messages were exchanged between England and Canada in 1902, and a public service was opened in 1907. For direct transmission by the long-wave system the estimated power to the aerial amounted to something like 1,000 kilowatts, the stations were to cost more than $£ 1,000,000$ each, the wave-lengths were to be of the order of 18 miles, and the aerials were to be carried on towers about 800 feet high. These figures now seem fantastic. As the result of a series of tests between the experimental station at Poldhu and Marconi's yacht Elettra, in 1923 and 1924, the short-wave beam system was evolved which enabled the Marconi Company to make an offer to the Post Office to establish communication with the Dominions using a fiftieth of the power, involving a twentieth of the cost, and providing a speed of working at least three times as great as that which was possible with the earlier long-wave system of communication. Experiments in telephony by wireless were first carried out by the Marconi Company in 1906, and it is claimed that there are now 180 Marconi broadcasting stations in use in 32 countries. It is estimated that the wireless industry employs 50,000 workpeople in Great Britain, and that the British radio industry alone has a turnover of $£ 30,000,000$ per annum.

\section{Z0o: A New Periodical}

THE Zoological Society of London has begun a venture which rounds off its benefactions to the nation. For well over a century its collections have amused and instructed the general public, it has spent vast sums upon the publication of scientific papers for the learned, and now in a popular monthly magazine it proposes to bring the interest of the zoo to those who cannot visit the enclosures, and generally to diffuse a knowledge of animals and their ways. Britain has lagged far behind the United States in the production of high-class popular magazines of science: we know nothing that can compare with Natural History, the journal of the American Museum of Natural History. But Zoo, in the quality of its text and in the interest and character of its illustrations, comes near to the American standard, and from the popular view it has gone one better, in leaving the stricter path of knowledge and introducing lighter stories of wild life. Many of the articles in the first number are by well-known scientific workers, and it is a pleasure to see that they possess the art of driving the pen so that the plain man can read.

\section{Cultivation of Cherries and Soft Fruits}

THe healthy and expanding state of the fruit. growing industry in Great Britain is evident from the Royal Horticultural Society's report on the con. ference on cherries and soft fruits held in July last. This follows a similar report of the conference on apples and pears held in 1934. The chairman, Sir Daniel Hall, expressed the opinion in his opening address that no other branch of agriculture has profited so much from the findings of research, and this close connexion between the industry and the various research institutions is fully borne out by the papers read at the conference. These are con. tributed equally by officers of the research stations and commercial fruit growers, and display a close co-ordination between the two points of view. The subjects dealt with embrace every aspect of the soft fruit industry, particular attention being devoted to cultural problems and the control of pests and diseases, whilst extensive data are presented concerm. ing manurial treatment and the effects of certain mineral deficiencies. A symposium on strawberry cultivation indicates the widespread interest in this fruit and the anxiety of both growers and research workers to deal with the numerous pests which have depleted the crop in recent years. Much information is given regarding the characteristics of varieties of cherries, raspberries and loganberries, and the qualities of fruit required for canning and bottling are also discussed. Copies of the report, price 6s., may be had from the Royal Horticultural Society, Vincent Square, S.W.1.

\section{Greenkeeping Research}

EVERY question connected with turf production and maintenance comes under review at the St. Ives Research Station, Bingley, Yorks, and a perusal of the Report for 1935 published by the Board of Green. keeping Research shows how rapidly both the experimental and advisory work have developed since the Station was founded in 1929. The bulk of the monery required to finance the work is subscribed by British golf clubs through the national unions. Free postal 